$18: 1294$

<原 著 $>$

肝線維症および肝硬変症に拉けるエンドトキシン

体内分布の実験的検討

白井 睦訓* 吉村吾志夫** 西岡 幹夫*
志賀 淳治*** 森 $\quad$ 亘***

要 旨: $\mathrm{CCl}_{4}$ 肝障害ラットに ${ }^{3} \mathrm{H}$ 標識エンドトキシンを投与し, その動態, 蔵器分布, 組織内局 在について検討した. Wistar 系雄性ラットにフェノバルビタール水のみを飲水させた対照群， 加えて $\mathrm{CCl}_{4}$ 吸入を施行し作成した肝線維症群，より長期の $\mathrm{CCl}_{4}$ 吊入を行い作成した肝硬変群 （各群 $\mathrm{N}=5$ ）の全動物につき，体重 $1 \mathrm{~g}$ あたり $12,000 \mathrm{CPM}$ の $^{3} \mathrm{H}$ 標識エンドトキシンを静注し, その24時間後に屠殺した. 各臓器のオートラジオグラフィーでは, ${ }^{3} \mathrm{H}$ 標識エンドトキシンの集 積は肝 Kupffer 細胞に目立ったが，肝での集積量は対照群に比べ他の 2 群で著减していた。歲 器中 ${ }^{3} \mathrm{H}$ 標識エンドトキシンの定量の結果, 対照群に比し肝線維症群, 肝硬変群ではエンドトキ シンは脾, 肺, 血中で増加し, 肝組織中で有意に減少しており,これら 2 疾患における肝のエ ンドトキシン処理能の低下と，それに起因したェンドトキシン血症の発生という一連の機序が 示唆された.

卖引用語：肝線維症肝硬変症 エンドトキシン エンドトキシン血症

Lipopolysaccharide

緒 言

肝疾患の際にエンドトキシン血症が高率に発生する ことが報告されておりり 特に肝硬変症においててその 発生率が注目されてきた。エンドトキシンの大きな作 用の一つとして, 血管内凝固症候群 (DIC)の発現分知 られるが4), 肝硬変症では血小板数, 凝固因子などの減 少による潜在的出血傾向がある上に，血中線溶活性の 異常六進を伴う例が多く"，エンドトキシン血症によ り惹起されるDICの発生が危惧される。

既に私共は肝部分切除後の肝再生極期において，肝 がエンドトキシンに対し易障害性を示し6 8)，また肝の エンドトキシン処理能低下からエンドトキシン血症を

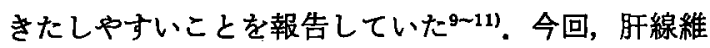
症, 肝硬変症ラットモデルを用いて肝のエンドトキシ ン処理能, ならびに血中をはじめ各葴器中のエンドト キシンの分布などについて検討し，興味ある知見を得 たので報告する.

* 香川医科大学第 3 内科

** 昭和大学医学部藤ヶ丘病院腎臓内科

*** 東京大学医学部病理学教室

<受付日62年 2 月23日>
材料と方法

\section{1. ${ }^{3} \mathbf{H}$ 標識エンドトキシンの作裴}

${ }^{3} \mathrm{H}$ 標識エンドトキシンは，既報と同じ方法 ${ }^{9 \sim 11)}$ で作 製した.すなおち, A1 epi UDP galactose-4-epimerase 欠損 Salmonella anatum $の$ L-broth 培地 ${ }^{3} \mathrm{H}$ 標識 galactose を加え，同菌に galactose 部分で ${ }^{3} \mathrm{H}$ を標識 した. Lipopolysaccharide (LPS) を産生させ，この LPS をフェノールー水抽出, 透析後, 超遠心を施行し精 製した。

\section{2. 動物実験}

Wistar 采雄性ラット（体重：150 200g）に领料水 として0.5g/lのフェノバルビタール水 (P水)の投与 を10週行ったラットを対照群 (control 群：N=5) と し, $\mathrm{P}$ 水の飲水に加之, 週 2 回, 1 回 3 分間の四塩化炭 素 $\left(\mathrm{CCl}_{4}\right)$ 吸入 ${ }^{13)}$ 密閉箱中で 6 週行ったラットを肝 線維症群( $\mathrm{LF}$ 群 : N=5), $\mathrm{P}$ 水领水と $\mathrm{CCl}_{4}$ 吸入を10週 行い, 肝硬変をみるに至ったラットを肝硬変群 (LC 群：N=5)とした。これらラットすべてに, 前記のご とく精製した LPS $12,000 \mathrm{CPM} /$ 体重1g を尾静脈より 投与し，その24時間後に全例屠殺した.

全動物につき，採取した肝，脾，肺，腎，副堅，腸， 脺の諸臓器に既報10,11) と同様にオートラシシォクラ 
フィーを施行し，さらに肝，脾，肺および血液の各臓 器の一部について sample oxidizer (Packard tri-carb sample oxidizer model 306) で処理後, 各葴器中の ${ }^{3} \mathrm{H}$-LPS 量 (CPM) を定量した ${ }^{911}$.

統計学的検討はすべて Student $t$ test によって行っ た.

\section{結 果 \\ 1. 組織学的検討}

control 群ラットの肝では，線維化など肝障害の所 見を認めなかったのに対し，LC群では著しい線維の 増生による完全な小葉構造の改築像がみられ，ヒトに みられる肝硬変の組織像に酷似していた(Fig. 1). LF 群の肝では bridging fibrosisが著明であったが，小葉 構造の改築によるいわゆる輪状構造を呈するには至っ

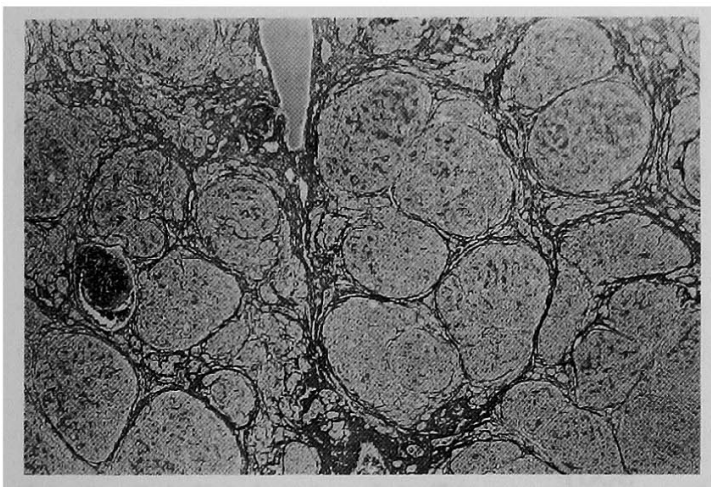

Fig. 1 Regenerative parenchymal nodules completely alters normal lobular architecture in the liver of rats, given $\mathrm{CCl}_{4}$ for 10 weeks (Silverstain, $\times 40$ ).

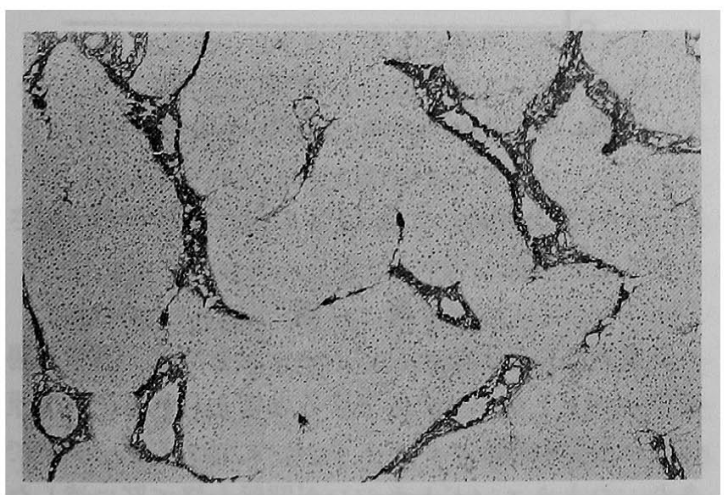

Fig. 2 Severe bridging fibrosis is observed in the liver of rats, given $\mathrm{CCl}_{4}$ for 6weeks. However, normal lobular architecture remains to be seen (Silver-stain, $\times 40$ ).

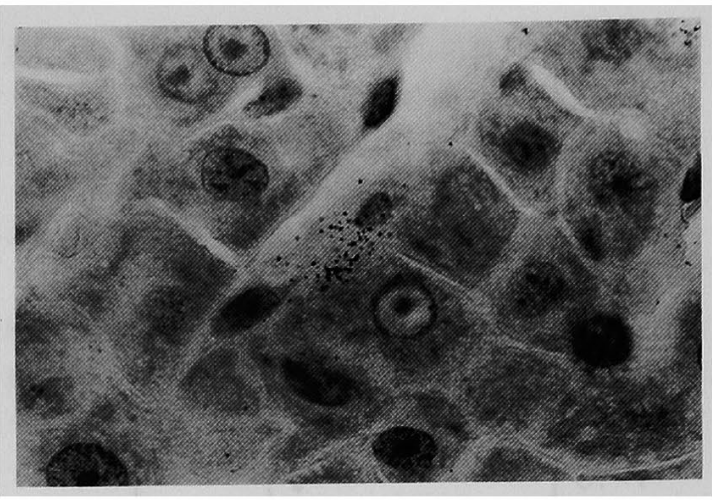

Fig. $3{ }^{3} \mathrm{H}$ labeled endotoxin is mainly taken up by Kupffer cells in the liver of normal control rats on autoradiography $(\times 600)$.

ていなかった (Fig. 2).

これら動物の諸藏器のオートラジオグラフィーの成 績では, ${ }^{3} \mathrm{H}$-LPS は肝を中心に脾, 肺にも多く分布して いた. control 群ラットの肝に括いては, び漫性に ${ }^{3}$ H-LPSの分布を認め，そのほとんどはKupffer細胞 に取り込まれていたが(Fig. 3)，一部は類洞内のマク ロファーシ，顆粒球の婹か肝細胞にも分布していた。 肝小葉内での局在については特に一定の傾向はなかっ た.こうした肝内での LPS の分布様式は LF, LCの 2 群でもほぼ同様であったが，その分布量は control 群 に比べ顕著に减少していた。 またLF，LC群ではKupffer 細胞数の増加がみられたが，個々の細胞における ${ }^{3} \mathrm{H}-\mathrm{LPS}$ の取り込み量は control 群のそれに比べ明ら かに減少していた。

一方, 各群とも肝以外の主な LPS 取り込み臓器は脾 と肺であったが, 脾では LPS は静脈洞壁あるいは静脈 洞内のマクロファージを中心に取り込まれて打り，肺 でも LPS の取り込みは主として肺胞隔壁や肺胞内の マクロファージにみられた，その他の葴器ではごく少 量の LPSの分布を散見するのみであり，その汪とんど は脈管中にみられた。

\section{2. ${ }^{3} H-L P S の$ 定量的検討}

液体シンチレーションカウンターによる radioactivity (CPM) 測定に基つくく，単位重量あたり の肝, 脾, 肺おょび血液中への LPS の集積量を検討 した. 肝 $(2.0 \mathrm{~g})$ への ${ }^{3} \mathrm{H}$-LPS の集積は control 群で

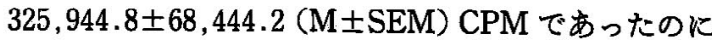

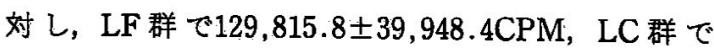
$132,500.2 \pm 25,442.6 \mathrm{CPM}$ といずれも control 群より 有意（p<0.01）K低下していた（Fig. 4). 


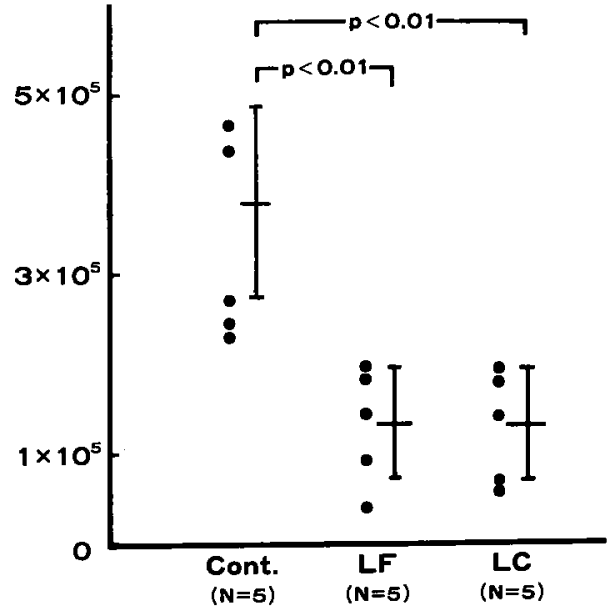

Fig. 4 Distribution of LPS in the liver.

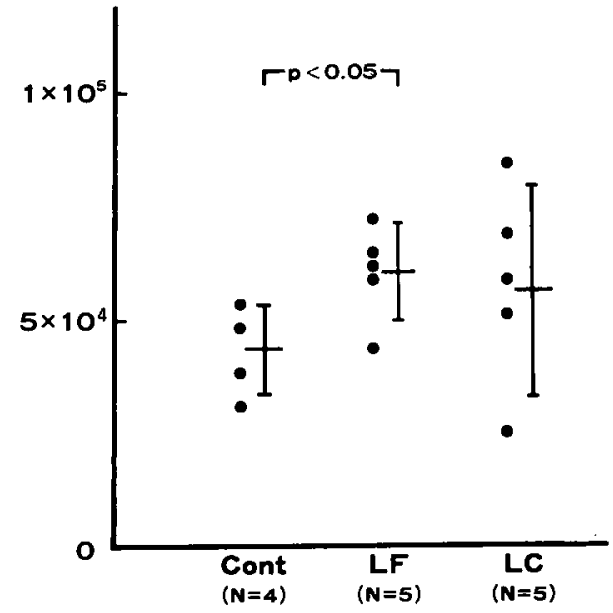

Fig. 5 Distribution of LPS in the spleen.

脾 $(0.5 \mathrm{~g})$ での LPS 集積量は, control 群 (control 群の脾の CPM 値のみ $\mathrm{N}=4$ ）の433,564.8

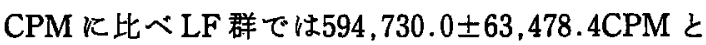
有意 $(p<0.05)$ に増加して括り，LC群でも568,754.0 $\pm 145,921$.3CPM と増加傾向を認めた（Fig. 5).肺 (1.0g) についてる同様で, control 群に比して, ${ }^{3} \mathrm{H}$ LPS 量は LF 群では有意 $(\mathrm{p}<0.01)$ に増加し， LC 群 では増加傾向を示した(Fig. 6).これら脾，肺0.1g中 における LPS の集積量は，LF 群において LC 群より もやや高い値を示した，血液 $(20 \mu l)$ への LPS 集積量 は control 群に比へ，LF 群では増加傾向，LC群では 有意な増加を示した（Fig. 7).

なお， control 群ラットの䔬便中には，多量の ${ }^{3} \mathrm{H}$.

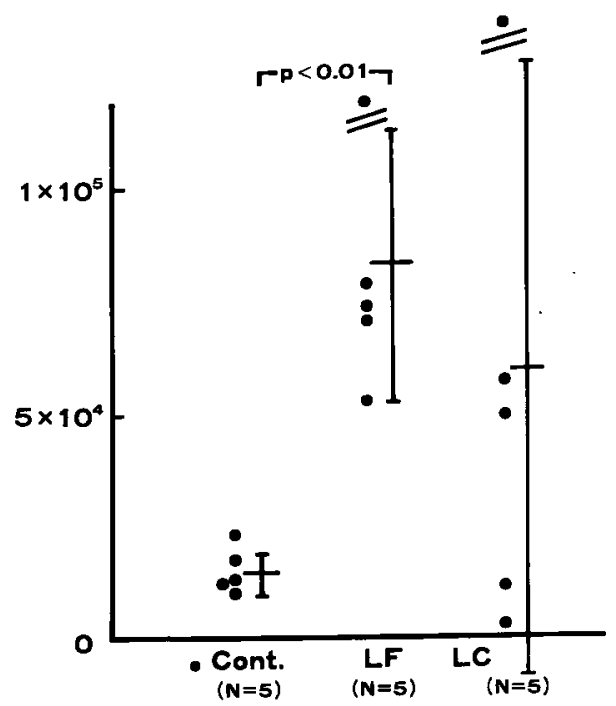

Fig. 6 Distribution of LPS in the lung.

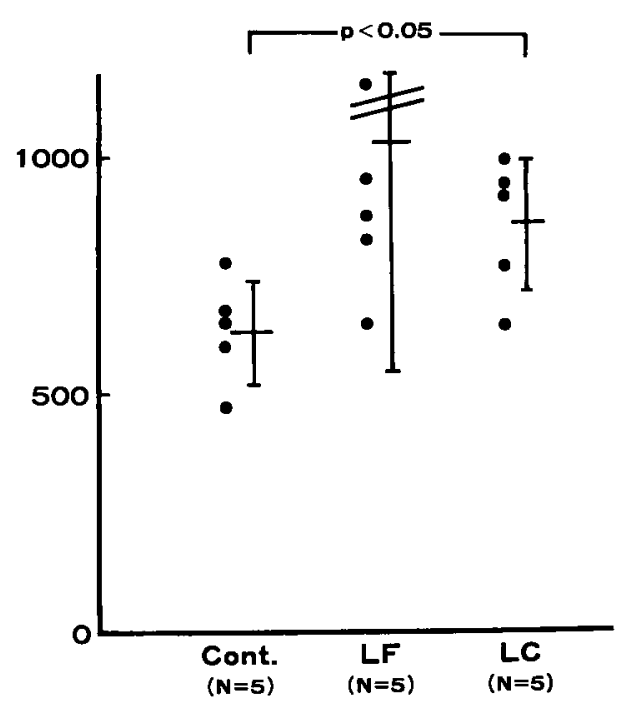

Fig. 7 Distribution of LPS in the blood.

LPS の排泄を認め，大量 LPS の胆汁中排泄が示唆さ れたことを付記しておく.

\section{考 察}

肝疾患でみられるエンドトキシン血症は，通常，腸 管内エンドトキシンに由来すると考えられる ${ }^{14)}$. 健康 体では腸管粘膜がェンドトキシンに対する第一関門で あり，たとえエンドトキシンが門脈を経て肝に達した としても，肝 Kupffer 細胞を中心とした細網内皮系 (網内系)に取り込まれ，分解作用を受ける ${ }^{15)}$. しかし， 肝疾患，なかでも肝硬変では胆汁酸分泌の減少や細菌 
叢の変化による腸管粘膜 barrier の破綻が起こり ${ }^{14)}$, 門脈血中に入ったエンドトキシンは門脈一全身循環の 短絡により全身循環に流出するが， あるいは肝に到 達しても，肝の Kupffer 細胞を中心とした網内系機能 低下 ${ }^{15)}$ によりェンドトキシン解毒能が低下しているた め,エンドトキシン血症が発生することが想定される。 こらして生じたェンドトキシン血症は, 微小循環障害 に起因すると思われる重篤な肝障害17)を起こすばかり でなく，肺，腎など重要な諸葴器の障害をきたし死に 至ることもある. 近年, こうした複数の臓器障害は multiple organ failure ${ }^{18)}$ と呼ばれ，その原因としての エンドトキシン血症が注目されている. したがって, 肝疾患, なかでも肝硬変症時の肝のエンドトキシンそ のものに対する処理能を検討するととひに，どの程度 のエンドトキシン血症が発生し，その際，諸臟器に招 いてェンドトキシンがぞれたけ集積しているかを知る ことは, 肝疾患時の Multiple organ faliure の発生機 構の解明上重要であるばかりでなく，エンドトキシン 血症の発生機序をより詳細に，かつより直接的に調べ る上でも重要な研究課題である.

本研究では，肝硬变症扔よびそれに至る以前の病変 である肝線維症の際には, 肝の単位重量あたりのエン ドトキシン処理能は著しく低下しており，オートラシ オグラフィーによる検討からここの処理能低下はェン ドトキシンの解毒関する肝内網内系機能の低下を反 映していると考えられた。 また血中ェンドトキシン濃 度は, 肝硬変症時には control 群より明らかに高く, 肝 硬変症時のエンドトキシン血症の高い発生率を支持す る成績であった，LF，LCの 2 群で，脾と肺への集積 量が対照群に比して多かったが，これは肝でのェンド トキシン処理能の低下を代償する作用と解釈できる。 ただそその際，LF 群の方が LC群よりむむしろ高い值 を示した。これについては肝外のマクロファージをは しめとする網内系の機能が肝硬变において,より著し く低下している可能性もあるが，未だ詳細は不明であ ク, 今後さらに検討の必要がある.

今回の検討の結果として, 肝硬变症がメンドトキシ ン血症とい5，いわば種々の病態の“引き金”因子を 発生しやすい状態であるといら観点から，肝硬变症は 重篤な病態に移行しやすいある種の集備状態といい得 ると思われる，また，この準備状態は，私共が報告し てきた䁍器性 Schwartzman 反応の準備状態 79 によよ く似て怙り, 今後, 実際の臨床の場で肝硬变症時にェ ンドトキシン血症の発生防止に務めるとともに, 肝硬
変症の病態を考える上で, こらした反応機構を思い置 くことも大切であることがあらためて痛感される。

\section{結語}

1. $\mathrm{CCl}_{4}$ 解障害ラットに ${ }^{3} \mathrm{H}$ 標識 LPSを投与し，そ の動態, 臓器分布, 組織内局在について検討した。

2. オートラシオグラフィー上, control 群では肝 Kupffer 細胞への ${ }^{3} \mathrm{H}-\mathrm{LPS}$ 取り込みが目立ったが，肝 線維症群, 肝硬変群ではその量は明らかに減少してい た.

3. ${ }^{3} \mathrm{H}-$ LPS の定量の結果, 肝線維症群および肝硬変 群の各葴器単位重量あたりの LPS 集積量は control 群のそれに比し, 脾, 肺, 血中で増加し, 肝では減少 していた.

4. 肝線維症および肝硬変症時の肝, とりわけその Kupffer 細胞を中心とする網内系のエンドトキシン血 症の発生と、それによる肝をはじめとする臟器障害作 用といら一連の機序が示唆された。

本研究に関して御協力を賜った東京大学医科学研究所 金ヶ崎士朗教授に深謝致します。

本研究は，一部文部省科学研究費の補助によって行われ ました。

\section{文 献}

1) Caridis DT, Fine J, Reinhold RB, et al: Endotoxemia in man. Lancet $\mathrm{i}$ : 1381-1385, 1972

2) Nolan JP, Ali MV: Endotoxin and liver. I. Toxicity in rats with choline deficient fatty liver. Proc Soc Exp Biol Med 129 : 29-31, 1968

3) Prytz H, Holst-Christensen J, Korner B, et al : Portal venous and systemic endotoxemia in patients without liver disease and systemic endotoxemia in patients with cirrhosis. Scand J Gastroent 11 : 875-863, 1976

4) Mckay DG, Shapiro SS: Alteration in the blood coagulation system induced by bacterial endotoxin. I. In vivo (generalized Shwartzman reaction). J Exp Med 107 : 353-367, 1958

5) Astrup T, Ramussen J, Amerry A: Fibrinolytic activity of cirrhotic liver. Nature $185: 619$ $-620,1960$

6）白井睦訓, 志賀淳治, 森：エンドトキシンに 上る肝部分切除後残存肝の高度壊死。肝臟 25 ： 933, 1984

7) 白井睦訓, 志賀淳治, 森 亘：肝部分切除術後の 急性肝壊死発生機序に関する実験的検討，肝臓 
$26: 1465-1471, \quad 1985$

8）白井睦訓, 志賀淳治, 森亘 : 肝切除術後急性肝 壊死の剖検例における検討, 肝胆脺 $12: 277$ $-283,1986$

9）白井睦訓, 志賀淳治, 森 亘：肝部分切除後ラッ トに抢けるェンドトキシンの体内分布の定量的検 討. 肝藏 $26: 944,1985$

10）白井睦訓，西岡幹夫，志賀淳治：肝部分切除後ラッ トにおける3 H-エンドトキシンの体内分布に関す る検討. 䀒葴 $27: 37-42,1987$

11）志賀淳治, 白井睦訓：肝部分切除後ラットにおけ るエンドトキシンの体内分布についての検討. 文 部省, 生物トキシン班会議60年度報告, in press

12) Westphal $O$, Jann $K$ : Bacterial lipopolysaccharides, extraction with phenol-water and further applications of the procedure. Methods in Carbohydrate Chemistry $5: 83-91,1965$

13) Cameron GR, Karunaratne EAE: Carbon tetrachloride cirrhosis in relation to liver regeneration. J Pathol 42 : 1-21, 1936
14) Kocsár LT, Bertók L, Várterész V: Effect of bile acids on the intestinal absorption of endotoxin in rats. J Bacteriol $100: 220-223,1969$

15) Olkay I, Kitahama A, Miller $R$, et al: Reticuloendothelial dysfunction and endotoxemia following portal occlusion. Surgery $75: 64$ $-70,1974$

16) Nolan JP, Camara DS : Emdotoxin, sinusoidal cells and liver injury. In Progress in liver diseases, Ed by Popper H, Schaffner F, Grune \& Stratton, new York, 1982, Vol. 7, p361-376

17) Nolan JP: The role of endotoxin in liver injury. Gastroenterology 69 : 1346-1356, 1975

18) Eiseman B, Beart R, Norton L: Multiple organ failure. Surg Gynecol obstet 144: 323 -326, 1977

19) Mori $W$ : The Shwartzman reaction : a review including clinical manifestations and proposal for a univisceral or single organ third type. Histopathology 5 : 113-116, 1981

\title{
Organ Distribution of ${ }^{3} \mathrm{H}$-endotoxin in rats with liver fibrosis and those with liver cirrhosis
}

\author{
Mutsunori SHIRAI*, Goshio YoshIMURA**, Mikio NishroKA*, \\ Junji SHIGA*** and Wataru MoRi***
}

The organ distribution and histological localization of ${ }^{3} \mathrm{H}$-labeled endotoxin were investigated in rats with $\mathrm{CCl}_{4}$-induced liver injury. Wistar male rats were given water containing phenobarbital (Control. $\mathrm{N}=5$ ) or given water containing phenobarbital and $\mathrm{CCl}_{4}$. Rats given $\mathrm{CCl}_{4}$ for 6 weeks showed liver fibrosis (Group LF, N=5) while those given it for 10 weeks showed liver cirrhosis (Group LC, $\mathrm{N}=5$ ). Animals were sacrificed and examined $24 \mathrm{~h}$ after an intravenous injection of ${ }^{3} \mathrm{H}$-labeled endotoxin (12000 CPM/ $1 \mathrm{~g}$ body weight). ${ }^{3} \mathrm{H}$-labeled endotoxin was taken up mainly by Kupffer cells in the liver but also by macrophages in the spleen and other organs. The measured amount of ${ }^{3} \mathrm{H}$-labeled endotoxin per $0.1 \mathrm{~g}$ organ weight of the spleen, lung and blood increased, while that of the liver significantly decreased in the rats of groups LF and LC, compared with those of the control rats. It is suggested that endotoxemia may be induced by deficient detoxication of endotoxin in liver fibrosis and liver cirrhosis.

* The Third Department of Internal Medicine, Kagawa Medical School (Kagawa)

** The Department of Internal Medicine, Fujigaoka Hospital, Shouwa University (Kanagawa)

*** The Department of Pathology, School of Medicine, Tokyo University (Tokyo) 